\title{
HORACE'S CLAIM TO FAME IN ODES BOOK 1: A QUESTION OF EXPECTATIONS?
}

\author{
S Thom (Stellenbosch University)
}

\begin{abstract}
The first book of Odes introduces the reader to a carefully conceived sequence of poems. This article argues that with this sequence a larger more philosophical Sitz im Leben ${ }^{1}$ is suggested for the individual poems as well as for the collection as a whole. This article further proposes that the careful construction of an individual book of Odes has a significant impact on the frame of reference of the collection as a whole. Odes book 1 is taken as an example substantiating this argument.
\end{abstract}

Horace's Odes is generally accepted as an exceptional achievement. ${ }^{2}$ In his Odes Horace does not portray only his mastery over poetic metre (his only claim to fame $)^{3}$ but much more. In this article I wish to concentrate on an accomplishment for which Horace made no claim, namely the overall construction of the individual books of Odes. ${ }^{4}$ This article proposes that the construction of the individual books of Odes makes a sizable if subtle philosophical contribution to the impact of those books - much as the metre supports the content of each poem. ${ }^{5}$ It also proposes

1 This article will not deal with the larger philosophical issues contemplated by the Epicureans and the Stoics, since Horace seems to move comfortably (or is that pragmatically?) between the two schools reflecting whatever point of view he finds most appropriate irrespective of its philosophical origin.

2 Von Albrecht 1995:290 sums up this exceptional achievement as follows: 'Sein Schaffen steht in seiner Art einsam da; es ist ausschliesslich seine persönliche Leistung'.

3 dicar ... / princeps Aeolium carmen ad Italos / deduxisse modos, Odes 1.3.10-14 (I shall be called the first to have transposed Aeolian song to Italian verse).

4 Since I accept the principle of 'from the claw the lion' I will take only book 1 into consideration in this article.

5 The article will focus on the effect of the poems in their particular order (as is, and is generally accepted, $c f$. Collinge 1961:36: 'The traditional arrangement is firmly based ...'). It does not claim that there is a single conclusive pattern to be determined in the order of the poems. For anyone who has spent any time with Horace's work, it would be obvious that a large number of different (and persuasive) patterns could be identified. Nisbet \& Hubbard's caveat (1970:xxiv) that 'ingenious reasons could be adduced to justify any arrangement' [of order] remains valid. This article does not insist on a specific grouping. It does not exclude different groupings of poems either. It simply wishes to take the sequence of the poems as they appear into account to determine a possible consequence for the reading of the book as a whole. Cf. Zetzel 1980:63: '... order of reading creates its own dramatic time ...' 
that even though Horace did not claim the construction of the books as accomplishment, it should nevertheless be considered as such. ${ }^{6}$

By successfully applying a wide range of Greek metres to Latin verse in his Odes Horace presents the reader with phenomenal technical mastery. The first book of Odes also introduces the reader to a carefully conceived sequence of poems. ${ }^{7}$ With this sequence Horace suggests that the order in which the poems appear may have something to add to the reader's experience of the whole. ${ }^{8}$ A striking juxtaposition of ideas in individual poems may enlarge the frame of reference for a specific poem. In the same way the sequence in which the reader meets certain poems can be suggestive of a larger frame of reference. This article does not intend to argue for a single possible grouping or for a fixed interpretation of the sequence in the different books of Odes. ${ }^{9}$ Its much more modest claim is that Horace sets the stage for the cameo performances of individual poems in the meticulously judged sequence of poems in individual books. In short, the larger world in which the poems have their Sitz im Leben is hinted at in the order in which the poems follow one another. This would imply that the sequence of the poems is as suggestive of the context as the metre is basic to the content of each poem. ${ }^{10}$

In this article I therefore argue that in Odes book 1 an account of the poet's view of the world is presented as sustained background reflected in the sequence of the poems in the book rather than explicitly worked out in each separate poem. Individual meaning as portrayed in discrete poems therefore must be understood

6 This article accepts the traditional arrangement of the poems. It does not, however, propose a formal poetological or meta-poetic design (Van Sickle, 2004:vii) for the construction of the individual books of Odes. Horace was a poet, not a systems designer. However, it cannot be denied that he had a remarkable grasp of structure.

7 There is support for a deliberate arrangement of the odes (Kiessling 1881 and Santirocco 1985) and vehement argument against it (Nisbet \& Hubbard, 1970). The possible result of reading of the poems in sequential order (and thereby implicitly accepting a deliberate arrangement) is discussed in this article. This reading does not claim to be definitive.

8 As Collinge 1961:37 already pointed out: '... Horace himself might very well have produced a dozen different groupings on a dozen different days, and achieved much with each one' which does not imply that the traditional sequence is not firmly established.

9 Cf. Schenker 1993:147 who points out that [Horace] not infrequently seems to embrace, simultaneously, two or more mutually exclusive positions.

10 Contra Collinge 1961:41 who states 'repetition of topics and ideas is so integral a part of Horace's lyric method as to preclude its having special force in purposeful juxtaposing of individual poems'. He does come to the conclusion, though, that 'there is a little more complexity than is generally recognized in the arrangement of the completed Odes by their author ...' (1961:55). It is this 'little more complexity' that I wish to trace in this article. 
also in terms of the effect contributed by the sequence of poems as they appear in the entire book. ${ }^{11}$ The on-going expression of the poet's view of the world encapsulated in one poem following another in a specific order is therefore part of the basic structure of the book. The world hinted at by the sequence of the poems, functions as a stage where aspects of the human drama portrayed by the individual poems are played out.

By means of the sequence of the poems in Odes book 1 Horace suggests his vision of the world in which the individual exists. ${ }^{12}$ Horace was not interested in portraying a systematic view of the world. What interested him deeply was the interaction between the individual and his circumstances - whether this was a person's response to the self, to others, to individual circumstances, to society, or, with regard to human beings in general, to their relationship to the cosmos. It therefore follows that if the poet intended to present a personal perspective on the human condition, his view of the world would form the basis for this portrayal.

When Horace published his Odes books $1-3$ in $23 \mathrm{BC}$, his previous work gave no indication of what could be expected in this new publication. ${ }^{13}$ In $30 \mathrm{BC}$ Horace had published his Sermones (or Satires) in which he commented in an understated manner on the foibles of human nature. A year later the Epodes were published. They rivalled some of Catullus' work in their harsh tone, aggressive metre and scathing invective. All this depicted a poet critical of his particular environment, but no indication was given of a broader perspective or of a view of the world as such. This had to wait for Horace's publication of his Odes or Carmina in 23 BC..$^{14}$

In Odes book 1 Horace puts forward his view of the world not only in individual poems, but also in how those poems follow and affect one another. ${ }^{15}$ Two basic aspects define an individual's reality in this world, namely space and time. Horace seems to devote the first three poems in the collection (Odes 1.1-3)

11 Poems grouped according to a specific theme represent the building blocks for the construction of the book. However, the sustained larger interplay between individual thematic blocks or sections gives the whole its context (Umwelt).

12 If the individual has some insight into the larger environment in which he lives, this understanding may act as an aid to coping with this existence.

13 I accept the traditional range for the dates of Horace's oeuvre.

14 McClatchy 2002:9: 'That a poet who began as a cynical satirist should next turn to the creation of exquisite lyrics may just signal a poetic gift coming at last to its true maturity. Horace had labored for a considerable time ... over his odes, which, when read together, display a remarkable variety and finish ... he wove a single lyric tapestry on which plays the light and shade of human experience'.

15 In order to put forward a manageable account of the world view portrayed in an entire book ( 38 poems in book 1 ) it will not be possible to present here the detailed analysis of each poem mentioned in the article. 
to portray the space in which an individual exists and the next six poems (Odes 1.4-9) to reflect on the time allotted to such an individual. It is interesting to note that these first nine Odes are also known as the parade Odes, in which Horace is said to have paraded his mastery over different Greek lyric metres, claiming in one impressive introductory swoop to rival the Greeks at least in technical ability. It makes sense that in these nine poems the poet would also put forward his view of the world where the basic prerequisites for the human condition as reflected in space and time are presented.

\section{Odes book 1.1-1.3 (Space)}

\subsection{Odes 1.1: Position in the world determined by birth}

In Odes 1.1 (Maecenas atavis edite regibus, Maecenas offspring of kings) Horace gives an indication of an individual's personal space in the cosmic whole by listing the vastly dissimilar occupations which appeal to people in very different positions in life. ${ }^{16}$ As an introductory poem to a new collection this poem is unique. ${ }^{17}$ There is no acknowledgement of the poet's muse or of a particular poetic context. ${ }^{18}$ There is only a negative request to two muses that the instruments needed for the poet's profession not be withheld. ${ }^{19}$ The space occupied by this poet is in the world of the master craftsman, in the real world of work, not in the esoteric world of poetic inspiration. In fact, the entire introductory poem consists of a list of pursuits which eventually determine a person's standing in life. This list of occupations is comprehensive, including such positions as those held by the athlete, the politician, the farmer, the sailor, the merchant, the soldier, the hunter and, of course, the poet.

Any reader of this collection must have been struck by the humdrum focus of this introductory poem - a first poem in a new collection could surely not only

16 This introductory poem covers a number of aspects, not only the positioning of an individual in a private space.

$17 C f$. Pomeroy 1980:3: 'The first poem in a new poetry book is of paramount importance. As the first that a reader — or browser — would see, it acted as a virtual preface by giving some indication of the content and style of the whole collection'.

18 Catullus 1 (cui dono) appeals to a patrona virgo (line 9) for the continued existence (11.9-10) of his lepidum novum libellum; Tibullus' Book 1.1 addresses a list of typical Roman mythological beings (Ceres, Priapus, the Lares, Roman gods in general) to support the labours described in his first poem and by implication his entire poetic effort; Propertius' Book 1.1 addresses his friend Tullus, but the influence of the mythological world of Amor and Venus is paramount.

19 si neque tibias / Euterpe cohibet nec Polyhymnia / Lesboum refugit tendere barbiton, if Euterpe would not withhold the flutes and Polyhymnia not refuse to tune the lyre of Lesbos, 1.1.32-34. 
consist of a list of career opportunities (even if that list does include those exceptions who take it easy, 1.19-22). And with this feeling that there must be something more to the poem, the reader is enticed into the poet's world of work, the work needed to engage with the poetry of this unique poet.

The list of pursuits unfolding in this introductory poem gives an overview of the most basic factor that determines the position or space a person inhabits in the world. In the case of an individual this space depends on birth, relating both to status as well as with regard to personality and ability. The introductory lines of the poem mention the rank conferred by birth on Maecenas, Horace's patron (atavis edite regibus 1.1.1, born from kingly ancestors). The final lines mention the standing (or possible standing) conferred on the poet depending on his ability (quodsi me lyricis vatibus inseris, / sublimi feriam sidera vertice, 1.1.35-36, but if you place me amongst the lyric poets, I will touch the stars with my head in acclaim). In general though, people have individual preferences and abilities suited to individual pursuits. On the whole such pursuits eventually determine status, or more precisely the space or environment which a person inhabits. ${ }^{20}$

\subsection{Odes 1.2: Position in the world determined by external circumstances}

This space inhabited by the individual is not only subject to personal effort or preferences. The space is also determined by cosmic circumstances beyond the individual's control. Immediately in the following poem, Odes 1.2 (iam satis terris nivis atque dirae / grandinis misit Pater, already the Father has sent to earth enough snow and dismal hail), the poet turns to this problem. The individual is subject to larger cosmic circumstances which can overturn the normal physical world completely. This second poem opens with a description of the age of Pyrrha where the known natural world was turned on its head by a massive flood, where fish stuck to the tree tops ${ }^{21}$ and deer swam the plains. ${ }^{22}$

More recently for Horace, the known social world, too, was subjected to overwhelming upheaval. ${ }^{23}$ During the previous century social values were completely overturned first in the bellum civile and then, towards the end of the

20 This is not the place to discuss the concept so firmly supported by Seneca (Epistulae morales) that character should determine a person's status, not his occupation.

21 piscium et summa genus haesit ulmo, and the family of fish clung to the top of the elmtree, 1.2.9.

22 et superiecto pavidae natarunt / aequore dammae, and the terrified does swam the allcovering water, 1.2.11-12.

23. civis acuisse ferrum [our youth will hear that] citizen sharpened the blade [against citizen] 1.2.21. 
Republic, by the subsequent on-going battle to establish power. ${ }^{24}$ This second poem in the collection therefore draws one clear conclusion. The individual can (and given his birth, only to a limited extent) determine his personal situation in space by his own efforts. The cosmic order, ${ }^{25}$ like the socio-political order, however, is beyond the control of the individual. This cosmic order (or lack of such order) determines the individual's position vis-à-vis his larger natural and social environment.

\subsection{Odes 1.3: Position in the world summarised}

The last poem in this section on space, Odes 1.3 (sic te diva potens Cypri, may the goddess ruling over Cyprus) offers a tentative summary of the types of space affecting the individual. The connection is made between the physical and larger environmental 'cosmic' space ${ }^{26}$ in which the individual finds himself (as reflected in the first two poems) and the mental space which he determines for himself.

It is part of human nature to see the unknown as a challenge. The unknown is there to become known, to be conquered. This third poem on space therefore includes an example of an individual transcending his particular geographic space, by means of personal effort, for instance by conquering the sea (1.3.9-20). The poem also includes examples of individuals trying to overcome other limitations imposed by the cosmic or larger environmental order, even though those limitations are understood never to be under the individual's control (1.3.21-40). The first two poems of the collection established man's position in space in terms of circumstances over which he had no control (birth, personality, socio-political environment). This third poem portrays man's position as being subject to his own authority as well as being dependent on external circumstances completely beyond his own influence. It is important to note that this third poem in the collection, is dedicated to Horace's friend and fellow poet, Vergil, who is about to undertake a journey. The fact of the voyage is Vergil's own decision. The outcome of the journey, however, depends on forces completely beyond Vergil's power to control. Vergil's journey turns into an extended metaphor for a life journey reflecting the decisions and the struggle required to get from one place to another, to move from one space in order to inhabit another. This effort can be seen

24 For aid under dire natural disaster conditions, help is sought from the gods. For help in social upheaval, society looks to its leaders. The poem, however, implies that help is not forthcoming, not from the gods and not from those in leading positions either.

25 In the Odes an abstract cosmic order is presented as concrete. It is manifested in the larger environment in which human beings have their existence.

26 Figuratively speaking neither the underworld nor the gods above are free from man's efforts to encroach on these aspects of the cosmos commonly impenetrable to man. 
as either a legitimate attempt or as folly. ${ }^{27}$ At the same time this journey also becomes a metaphor for the labour required to move from an initial understanding of the poetic journey reflected throughout Horace's Odes to a more informed insight into the whole at the end of the collection. ${ }^{28}$

After the first three poems of Horace's new work, the reader is confronted with a number of conclusions regarding space. There is personal space, more or less under the individual's control. There is cosmic space, manifested inter alia in a natural and / or socio-political environment that has profound influence on the individual but which is beyond human control. Then there is a mind space where an attempt can be made to understand both personal space and the larger cosmic environment.

\section{Odes book 1.4-1.9 (Time)}

It follows that if the mind grapples with the problem of space, then the mind will also come to grips with the problem of time, since existence in one is a prerequisite for the other. In Odes book 1 the subject of time is under discussion in twice as many poems as the somewhat less complicated subject of space. In Odes book 1, in the six poems on time following the three poems on space, Horace sets out his view of the world as it relates to this fundamental aspect of human life.

\subsection{Odes 1.4: Time as determined by the natural cycle}

In Odes1.4 (solvitur acris hiems, bitter winter melts away) two aspects of time are underlined. All of human life is circumscribed by time. Time for human beings is linear and non-renewable. In Odes 1.4, the first poem in the series focusing on time, Horace gives the most basic discussion of time in the whole collection. Human activity is linked very closely to the seasons (1.4.1-4). Man and beast react to the first indications of spring. So, too, do the inhabitants of the mythological world (1.4.5-8), with one basic difference. The mythical entities (gods, goddesses, nymphs and Cyclops) are immortal. The lives of man and beast on the contrary are subject to a time limit. Mortality and the very brevity of life should prevent any illusions about time (vitae summa brevis spem nos vetat inchoare longam, the sum

27 Nisbet \& Hubbard 1970:42-43 underlines the awkwardness of combining a propemptikon with a diatribe on inventiveness.

28 This insight is closely connected to an understanding of the cosmology portrayed in the sequence of the poems in book 1. An individual can move from one physical space to another. It requires more courage to set sail for an unknown location as opposed to maintaining a current position. An individual can also move from one mental space to another. The attainment of a new insight (a new mental space) requires courage in the same way as setting sail for an unknown geographical location. 
total of a brief life forbids us to undertake long-lasting hope, 1.4.15). In this first poem on time the poet is at pains to underline that man, who responds so directly to the renewal associated with the seasons, has no part in the eternal regeneration linked to the seasonal cycle. Man is excluded from the most basic aspect of his own environment. ${ }^{29}$

\subsection{Odes 1.5: Time translated into experience}

In the next poem, Odes 1.5 (quis multa gracilis te puer in rosa, what slight youth [grips] you amongst many roses, Pyrrha,) Horace reviews an example of what an individual does with his non-renewable time; how an individual turns the time available to him into experience; how time as past experience, even if painful, can be used to benefit time in future. The poem emphasises the experience of the gracilis puer by addressing Pyrrha. She represents the experience and her description is central to the poem. By focusing on the impact of this unequal relationship, the fact of the experience is made real. In this way the gracilis puer in the first line can, in the last stanza, become the wiser poet looking back on an emotional shipwreck — but one which he survived.

\subsection{Odes 1.6: Time employed in the past, or transcending the natural cycle}

Odes 1.6 and 1.7 focus on further examples of individuals' use of time. However, just as achieving a specific position is shown to be under the individual's control in Ode 1.1 and completely beyond his control in Odes 1.2, time also is sometimes under the individual's control and sometimes not. In Odes 1.6 (scriberis Vario fortis et hostium, you [Agrippa] will be described as brave and as a conqueror of the enemy, by Varius ) the poet focuses on personal time under the control of the individual. The addressee, Agrippa, made such excellent use of his time that he is immortalised in poetry. However, as the poet implies - if with some irony - he, Horace too, made good use of his own time. After all, he wrote this poem as a recusatio refusing Augustus's general encouragement to write epic poetry to the glory of the state (and by implication the princeps) - a clear indication of an individual taking (maybe rather rash) control of his time. ${ }^{30}$

29 Nisbet \& Hubbard 1970:61 summarises Horace's achievement as follows: 'Horace has shown here as perhaps nowhere else his full power to fuse elements of totally different provenance'. In this poem the reader has to take into account both the hope of renewal and the despair of mortality.

30 Cf. Davis 1991:11-39 for a thorough discussion of Horace's use of recusatio. 


\subsection{Odes 1.7: Limited time for limited action, or the reality of human time}

Odes 1.7 (laudabunt alii claram Rhodon aut Mytilenen, others will praise famous Rhodes, or Mytilene ) focuses on personal time put to use according to both social and personal criteria, but in this case the individual is confronted with how little control he has over the time allotted to him. His time is largely determined by circumstances. All the individual can manage, whether he is a Plancus in the present or a Teucer from myth, is to focus rather fatalistically on those very limited aspects of time that are under his restricted control (sic tu sapiens finire memento / tristitiam vitaeque labores / molli ... mero, 1.7.17-19, so you too must wisely recall to bring to an end the sadness and efforts of life with soft (mellow) wine).

\subsection{Odes 1.8: Wasting time or ignoring the natural cycle}

It is, however, possible to spend even the limited time over which one has control in a completely wasteful manner. This is the focus of Odes 1.8 (Lydia, dic, per omnes, Lydia, tell me, by all the gods ) - a poem consisting only of rhetorical questions. These questions list real and mythological examples of time wasted. In its first three stanzas the poem focuses on a real example of unrequited love and its consequences (a typical lyric focus). The rejected lover wastes his time pursuing an impossible objective. (Lydia, dic, per omnes / te deos oro, Sybarin cur properes amando/ perdere, 8.1-3, Lydia, by all the gods, I ask you explain why you rush to ruin Sybaris by means of love.) As a consequence the rejected lover is deprived of both time and space. In the process of squandering time on an unattainable objective he alienates himself from every single space which previously he has made his own, where, in the past as a man of action, he spent time on obtainable objectives (1.8. 3-12). ${ }^{31}$

In the last stanza the poem focuses on a striking mythological example of time wasted. Achilles sulks and shirks his duty throughout a large section of Homer's epic the Iliad ${ }^{32}$ only to fulfill his destiny at last by dying on the battle field at Troy. ${ }^{33}$ Even the great Achilles had only imperfect control over the time allotted to him.

31 He can no longer live his earlier life, exercising in the Campus Martius (1.8.3-4), fighting the Gauls as a soldier (1.8.5-7), swimming in the Tiber (1.8.8), wrestling and practising to improve his skills with weapons (1.8.8-12).

32 He starts out wasting time by hiding away on Scyros in woman's clothing to avoid going to Troy at all (1.8.13-16). He ends up not fighting because of a slight to his person to enter the fray only after the death of Patroclos.

33 And only after his friend, wearing his armour, had died in his stead. 


\subsection{Odes 1.9: Human beings have only one life}

The final poem in the section on time, Odes 1.9 (vides ut alta stet nive candidum / Soracte, do you see how Soracte stands white with deep snow) contains a straightforward admonition not to let time pass one by. This sixth ode in the group focusing on time brings to an end the poet's preliminary sketching of space and time depicting a specific view of the world which in turn underlines the basis of a way of life. Time passes inexorably in Odes 1.9, as it does in Odes 1.4. Odes 1.9 concludes that death, like a visible mount Soracte, is omnipresent and cannot be ignored. It may be the height of winter at the beginning of the poem, but in the last stanza time has passed to such an extent that it is already spring. Space, too, is involved in the change of setting from a frozen, lifeless mountain far away in nature at the beginning of the poem to the life-filled square in the midst of a human community at the end. The individual lives his life sub specie aeternitatis and is bound by limits of both time and space.

\section{Odes book 1.4-1.9: Conclusion - Time and space}

The first nine odes form an introductory sketch by the poet of his view of the world. In these poems the poet illustrates how the natural order of the universe impacts on space and time in a human life. The next poem, Odes 1.10, functions as a preliminary assessment of this understanding.

\subsection{Odes 1.10: Concluding poem of the first time-space cycle}

Odes 1.10 (Mercuri, facunde nepos Atlantis, O Mercury, articulate grandson of Atlas) is the first poem in the collection in which the addressee is not a human being. There are references to the mythological world in the previous nine poems, but Odes 1.10 is the first poem in which the poet directly addresses a mythological being. It is therefore of basic importance to understand why Mercury is the particular addressee evoked in a poem that functions as an initial overview of the poetic world imbedded in the collection. ${ }^{34}$

Interestingly enough, the poet is indeed at pains to explain why Mercury is the addressee. ${ }^{35} \mathrm{He}$ is the grandson of Atlas, a Titan, who supports all of heaven on his shoulders. Poetically speaking all physical space therefore depends on this firm

34 The above reading posits that in addressing the poem to Mercury, Horace aims at achieving more with the poem and not only expressing 'an allegiance to the god of unassuming poetry, whimsical trickery, and gentle charm' (Nisbet \& Hubbard 1970:128).

35 Critics have long struggled with the interpretative possibilities of this poem. See Frankel's summary of problematic interpretations (1957:163-166). 
resting place. Mercury himself is described as clear-sighted, even cunning (catus). His objective is to change the mind-space of recently created human beings. He brings them from a state of ferocity to a state of enlightenment by the great gifts of speech and disciplined physical training (Mecuri ... qui feros cultus hominum recentum / voce formasti catus et decorae / more palaestrae, o Mercury ... who, with speech and the discipline of the formative wrestling ground, cunningly formed the wild instincts of recently created human beings, 1.10.1-4).

The importance of a change in mind-space or of a different perspective is illustrated in the middle section of the poem. ${ }^{36}$ Horace dedicates an entire stanza, the crux of his poem (1.10.9-12), to Mercury's wayward sense of humour, not directed at mortals but at Apollo himself, who is led to a different and unexpected understanding of a situation. Mercury brought Apollo to laugh at himself on being outwitted by a child who could not be frightened by threats (te, boves olim nisi reddidisses / per dolum amotas, puerum minaci / voce dum terret, viduos pharetra / risit Apollo, when you were a young boy, [o Mercury], Apollo, made verbal threats if you did not return his cattle stolen by wile, only to laugh at his (own) empty quiver, 1.10. 9-12). Even a god's use of language and threats does not always bring about the desired results. Even a god sometimes has imperfect control over the gift of language Mercury had brought to human beings. Even a god can be brought to a new understanding of a situation.

Horace concludes this poem by describing two fundamental changes in space. First, a reference to an historic change of physical space brought about under Mercury's guidance; a change of space most relevant for the onset of a history of Rome when Mercury watched over Priam's escape from Troy (1.10.1316). Secondly, Mercury also watches over the most important change of space for the individual. When physical time has run out for a human being, Mercury guides him from the known space of the physical world, to the unknown time and space of another realm. As messenger of the gods from above and from below (superis deorum / gratus et imis, 1.10.19-20), Mercury straddles the physical and the metaphysical world. As guide he helps those in his charge to navigate these different cosmologies to arrive safely in a different space with a different concept of time.

And with this insight in mind at the end of the first section (1.1-1.10) of Odes book 1 a next question follows naturally: what can be done with this insight regarding space and time?

36 As if in passing, Mercury is mentioned as the messenger of Jupiter and the gods, but more explicitly as father of the lyre, the instrument which serves as the very symbol of Horace's poetic mastery (te canam, magni Iovis et deorum / nuntium curvaeque lyrae parentem, 1.10.4-8). In Odes 1.1.33-34 Horace's request was that Polyhymnia should allow him to tune his lyre and practice his vocation. 
4. Odes book 1.11-1.14: Choices regarding time (a response to Odes book 1.1-1.10)

At the end of such a close-knit cycle portraying an initial exposition of a view of the world as reflected specifically in an assessment of time and space in Odes $1.1-1.10$, the reader finds himself in the position of asking: what now?

\subsection{Odes 1.11: Time in the future (carpe diem)}

Horace anticipates this question by the very first words of the next poem, Odes 1.11 (tu ne quaesieris - scire nefas - quem mihi, quem tibi / finem di dederint, do not try to find out how much time you still have (do not research what end the gods have in store for you or me). There are two ways to respond to the desire to control time or, to put it differently, to see the future. The individual can, as Leuconoë does in this poem, focus on the immediate physical world which may be revealed by calculations and the analysis of numbers. ${ }^{37}$ The focus could also be on the larger incalculable cosmos where the individual accepts that time is not under his own control. It is in this poem that one of Horace's most quoted sayings occurs: namely carpe diem (1.11.8). This maxim contains the positive admonition that Leuconoë (the addressee of the poem) should engage actively with the time that is at her disposal. By implication it also warns against squandering the present by anticipating a time that may (or may not) be available in future.

The gender of the addressee is noteworthy. In the first cycle on time (in book 1.4-9) the only two female addressees, Pyrrha (1.5) and Lydia (1.8), are both portrayed as consuming other people's time: ${ }^{38}$ Pyrrha is put in the position where she serves as an emotionally expensive learning experience for the young gracilis puer and Lydia seems to take pleasure in ruining Sybaris, who used to be a good man-of-action amongst comrades. In Odes 1.11, the first poem to respond to the time-space situation as set out in Odes book 1 (1.1-1.10), Leuconoë is portrayed as wasting her own time by trying to calculate how much of it is still left.

37 Since numbers, and the system governing numbers, respond to the will of the individual (not in outcome but in application), it is natural that individuals would attempt to use such systems to calculate specific outcomes or to control that which is not controllable.

38 For those who believe that Horace had an uncanny ability to manipulate the structure of his compositions in the smallest detail, it will not come as a surprise that these poems (1.5 and 1.8) follow immediately after the first and immediately before the last poem in the list of poems on time (Odes 1.4-1.9). 


\subsection{Odes 1.12: Time in the past}

In Odes 1.11 an individual engages in a futile endeavour to take possession of time in the future. In Odes 1.12 (quem virum aut heroa lyra vela acri / tibia sumis celebrare, Clio? What man, what hero do you take to celebrate on the lyre or on the sharp sounding flute, o Clio? 1.12.1-2) addressed to Clio, the muse of history, the poet takes the next logical step in the account of his view of the world depicted in the collection. The poet focuses on time in the past - that is mythological as well as historical time. History can confer a state, akin to immortality, where the individual, by being remembered, is no longer bound by the time limit associated with a normal life-span. Orpheus, who could influence even the rulers of the underworld with his lyre, is listed as a first example of a man who transcends physical space. Moving between physical space and space in the underworld signifies that the normal limitations characterizing space in the natural world have been transcended. ${ }^{39}$ This feat results in Orpheus not only leading Eurydice away from space in the underworld, but also transcending time by being immortalised in mythology.

The poem goes on to list the most important gods figuring in the mythological world (1.12.13-24). ${ }^{40}$ Mythological heroes, like Hercules, Castor and Pollux (1.12.25-32) are next in line followed by the heroes from Roman history (1.12.33-48). The list reflects two important aspects of time. An ordinary mortal can successfully transcend time (and enter history) only with the support of the larger cosmos as signified by the metaphor of immortals who help or hinder this achievement at will (1.12.49-60).

\subsection{Odes 1.13: Waste of time (personal circumstances)}

Odes 1.12 portrayed the rewards of time well-spent as indicated by remembrance in history or even transcendence into mythology. Two poems on time misspent flank this perspective. Leuconoë (in 1.11) has some time under her own control and should not squander this precious commodity on meaningless projections. The protagonist in Odes 1.13 (cum tu, Lydia, Telephi / cervicem roseam, cerea Telephi / laudas bracchia, vae, meum / fervens difficili bile tumet iecur, when you, Lydia, praise the light-skinned neck of Telephus, his arms like wax, alas, my burning heart swells with bile difficult to contain, 1.13.1-2) mismanages his time by allowing his emotions to overwhelm him. In the tradition of Sappho 31 and

39 It is important to note that the instrument needed for this achievement is the lyre, the symbol of the lyric poet.

40 They are: Jupiter (1.12.13-16), Pallas Athena (1.12.17-20), Bacchus (1.12.21), Diana (1.12.22-23) and Apollo (1.12.23-24). 
Catullus 51 the poet focuses on individual emotions, emphasizing an inability to control a single reaction. It is significant that in the larger scheme of things this reaction is a waste of precious time. A limited life-span with an imminent last day (suprema ... die, 1.13.20) should put things into a more realistic perspective. This rather harsh assessment puts the self-indulgence associated with excessive emotion into a context which underlines the waste involved when time is misspent.

\subsection{Odes 1.14: Waste of time (socio-political environment)}

In Odes 1.13 the individual lacks self-control. The result is that he wastes precious time even though this time is finite. In Odes 1.14 (o navis, referent in mare te novi / fluctus, o ship new waves drive you back to sea, 1.14.1-2) lack of control is again the theme, but in this case the individual is helpless to influence the larger environment in which he finds himself. The ship of state subjected to relentless onslaughts from nature is probably the best-known metaphor for portraying the helplessness of the individual to control his own social-political and physical environment. However, even in this situation the individual still has some control over his own reaction. In the last stanza the ship with its precious cargo (nunc desiderium curaque non levis, now my desire and unceasing care, 1.14.18) does have the option to attempt to lay a course for less dangerous waters. Horace's view of the world seems to suggest that even if the ship is at the mercy of the elements, some less threatening sea route might still be attempted. ${ }^{41}$ In the same way, even if the individual is completely at the mercy of his environment, some less destructive personal choices might still be possible.

\section{Odes book 1.15-1.17: Personal choice in literature}

Immediately following a poem on the vulnerability of the individual to a situation brought about by socio-political events in real time, the next cluster of poems (1.15-1.17) focuses on the exposure of an individual to events in a literary environment. ${ }^{42}$ These three poems (Odes book 1.15-17) form a natural unit. They also function as a type of intermezzo. They eternalize the more realistic environment of the previous 14 poems by means of references to the literary world. Each poem reflects the results of one individual's choice at a specific point in time. Each poem is worked out in terms of a different literary genre (epic, lyric and

${ }^{41}$ It seems suggestive that decisions made by statesmen have this quality of either exacerbating an already tense situation or diffusing it completely — all depending on the course steered.

42 Here the poet speculates on the outcome of an individual's choices in a world of literary situations, exemplified in a literary setting as portrayed in different literary genres. 
pastoral) representing as it were three possible poetic environments with a literary view of the world as background.

\subsection{Odes 1.15: Personal choice portrayed in epic}

In Odes 1.15 (pastor cum traheret per freta navibus Idaeis Helenen perfidus hospitam; when the treacherous shepherd rushed Helen his hostess away over the sea in Trojan ships ... 1.15.1-2) Paris's personal choice for Aphrodite eventually resulted in the abduction of Helen and the epic fall of Troy. A simple choice, understandable from a personal perspective, results in the destruction of an entire society.

\subsection{Odes 1.16: Personal choice portrayed in lyric poetry}

In Odes 1.16 (o matre pulchra filia pulchrior, o daughter more beautiful than your beautiful mother) the poet uses nearly the entire poem to describe the consequences of anger (1.16.5-21). The lack of self-control that accompanies anger makes it practically impossible to curb (1.16.5-9), putting it on a par to being possessed by some external force. It seems as if Horace is warning the woman in the poem (the filia pulchrior) that anger unchecked can have dire consequences. With the subtlety of a modern psychologist Horace does not exacerbate her anger, but rather ostensibly allows her to have her way (quem criminosis cumque voles modum / pones iambis, sive flamma / sive mari libet Hadriano, 1.16.2-4, give whatever end you want to my mean lines, either by burning or [drowning them] in the Adriatic). A general discourse on anger follows where Horace gives ample evidence of his thorough understanding of the topic. His empathy for anyone suffering from this condition is clear. He has smoothly prepared the way for the compesce mentem (calm yourself, 1.16.22) which he immediately follows by me quoque, indicating (as a fellow sufferer) his own susceptibility to this condition.

Horace has again underlined lyric poetry's unique ability to capture the individual and the individual's personality and relationships. Again the choice for the poet was simple. He used the tools of his trade (lyric poetry) to persuade the filia of his point of view. The result of a simple choice can be complex and hurtful, requiring retribution in the form of yet another poem admitting the dire effects of uncontrolled wrath. ${ }^{43}$

${ }^{43}$ irae Thyesten exitio gravi / stravere, wrath brought Thyestes down in terrible destruction, 1.16.17-18. 


\subsection{Odes 1.17: Personal choice portrayed in pastoral poetry}

Finally, in Odes 1.17 (velox amoenum saepe Lucretilem / mutat Lycaeo Faunus, swift Faunus often exchanges striking Lucretilis for Lycaeus, 1.17.1-2) the open possibilities and ideal environment of the pastoral genre are described as the only situation in which the consequences of individual choice do not seem retributive and harsh. ${ }^{44}$ Only in the idyllic world of pastoral poetry can the poet state with confidence that the gods are on his side and on the side of his muse (di me tuentur, dis pietas mea / et Musa cordi est (1.17.13-14).

The poet, however, lives in the real world. Odes book 1.18-1.22 turns to how the poet should respond, not to literary encounters, but to challenges in the present.

\section{Odes book 1.18-1.22: Choices regarding time (personal)}

These five poems (Odes 1.18-1.22) form a unit. They illustrate the basic premise regarding time as depicted in Odes book 1.4-9 by focusing on how the present impacts on the lyric poet and how this individual responds or should respond to the challenge of limited time. ${ }^{45}$ In these five poems the poet therefore turns his attention away from literary genres to focus on a depiction of his own immediate world.

\subsection{Odes 1.18: Live in the present, create something as hope for the future}

As opposed to the idyllic world of pastoral poetry, the poet's reality needs protection. This extraordinary protection is granted him by Bacchus, as god of inspiration, Apollo, as god of music and Venus as goddess of love with whom the lyric poet has a special relationship.

Odes 1.18 (nullam, Vare, sacra vite prius severis arborem; you should plant no tree rather than the sacred vine, o Varus ) encourages the planting of a vine specifically. The fruit of the vine above all else best supports the individual in coping with difficult circumstances in the present (neque / mordaces aliter diffugiunt sollicitudines, 1.18.3-4, and biting cares are not driven away in any other manner). At the same time, wine symbolizes an escape from the present, even from the limits of time, since the grape itself transcends its natural life-span when turned into wine. The complicated symbolism vested in the vine contains,

$44 C f$. Nisbet \& Hubbard's summary of the idyllic feeling portrayed by the poem (1970:216-217).

45 In Horace's poetry the middle section of a structure regularly reflects the crux of the matter under discussion. Odes 1.18 and 19 directly precede the middle of the collection, where the reader might expect some exposition of the crux of the whole book. 
simultaneously, an escape from the present as well as a paradoxical transcendence of time altogether. ${ }^{46}$ The poet's reality is at least as complex.

6.2 Odes 1.19: Motivation for the advice given in 1.18 or take control of the present

Odes 1.19 (mater saeva Cupidinum / Thebanaeque iubet me Semelae puer, the cruel mother of the Cupids together with the son of Theban Semele commands me, 1.19.1-2) illustrates how the advice given in the previous ode has practical consequences. It gives an example of how, after cultivation, the fruit of the vine supports the individual to overcome difficult circumstances in the present. Odes 1.19 is addressed to both the goddess of love and the god of wine, Venus and Bacchus, respectively. Venus has limited the poet's ability to act, or more specifically has prevented his writing about any other topic than love (me ... Venus ... nec patitur Scythas et ... animosum ... Parthum dicere, nec quae nihil attinent ..., Venus does not suffer me to write / talk about the Scythians or the bold Parthians, or whatever else is not relevant, 1.19.9-12). However, in the last stanza Bacchus, with the help of wine, supports the poet's attempt to write at least a love poem. With this poem the poet will have some control over his present circumstances, since, by doing her bidding, he will be able to petition the goddess for support. Ironically it is wine that helps him to do Venus's bidding and so overcome the initial handicap she placed on the poet.

The whole is also symbolic of how a person can take control of his time, to a limited extent as well as with some external aid, even when circumstances seem to be rather restrictive.

These two poems (Odes 1.18 and 1.19) together again express an important aspect of Horace's view of the world. Physical time is both limited and under the limited control of the individual. However, inspiration - as symbolized by Bacchus's support - helps the poet to transcend the moment by writing a poem that overcomes not only the restrictions of the moment, but also the limitations of physical time, since the poem, once written, escapes time altogether.

6.3 Odes 1.20: Celebrate achievements from the past or taking control of personal space

Horace dedicates Odes 1.20 (vile potabis modicis Sabinum, you will drink ordinary Sabine wine [with me]) the first poem of the second half of Odes book 1, to his

46 Nisbet \& Hubbard 1970:229 points out that Horace 'is playing a complicated literary game' in this poem. 
patron Maecenas ${ }^{47}$ just as he dedicated Odes 1.1, the first poem of the first half of the collection, to him. In the previous poem, Odes 1.19, wine was used to ease the pressures of the present moment. In so doing the individual took control of his time. In Odes 1.20 the crushed fruit of the vine is used to celebrate — in the present - a moment of individual achievement called forth from the past. ${ }^{48}$ The poem also subtly overcomes some constraints of space. Maecenas (1.20.5) may be used to a more luxurious environment (Caecubum ... tum tu bibes, 1.20.10, then you may drink Caecubum ...) but (even ordinary) wine offered to him in friendship is special, eliminating the relative social positions of the two friends on this occasion.

6.4 Odes 1.21: Reminder of the individual's lack of control over his larger environment; tempus fugit

Having just celebrated Maecenas' achievements in Odes 1.20, the next poem, Odes 1.21 (Dianam tenerae dicite virgines, young maidens, praise Diana) begs Apollo to keep at bay circumstances harmful to the present. Apollo should keep away war, famine and illness, ${ }^{49}$ the three great destroyers of human life over which the individual has no control, so that the individual's time span in which to realize his possible attainments not be curbed or even erased by external circumstances..$^{50}$

47 The terms of this invitation call to mind Catullus 13 (cenabis bene, mi Fabulle).

48 datus in theatro / cum tibi laudes, / care Maecenas eques, ut paterni / fluminis ripae simul et iocosa / redderet laudes tibi Vaticani / montis imago (Odes 1.20.3-8), when in the theatre you were applauded thus, dear knight Maecenas that the banks of your home river and the delighted echo of the Vatican hill acclaimed your honour). It is interesting to note that both in the first ode of the collection (Odes 1.1) and in this ode (Odes 1.20) Horace refers to Maecenas' birth (Odes 1.1 Maecenas atavis edite regibus; Odes 1.20 care Maecenas eques). In the final poem of the collection, where Horace refers to his own achievements, he too mentions his own situation at birth before going on to point out his specific poetic achievement (Odes 3.30.12-14: ex humili potens / princeps Aeolium Carmen ad Italos deduxisse modos).

49 hic bellum lacrimosum, hic miseram famem, pestemque a populo ... in / Persas atque Beritannos / vestra motus aget prece (Odes 1.21.13-16, touched by your prayer he will send tearful war, miserable famine and illness away from the people to the Parthians and Britons).

50 It may be that a positive request (asking the god to direct war, plague and famine elsewhere (in Persas atque Britannos, 1.21.15) has a better chance of being granted than a more general 'please do not...'. 
6.5. Odes 1.22: Further motivation for the advice in 1.18 or constructive use of inspiration protects against even dire external threats from the environment

Odes 1.22 (integer vitae scelerisque purus, a person of integrity and one free from guilt) brings to a close this group of five poems focusing on how the present impacts on the individual and his practical response to the challenges he faces. In this poem it is not Bacchus with his gift of wine who eases the stresses and strains of the present, but Venus's gift of love ${ }^{51}$ that protects the poet from life-threatening circumstances even in the poet's own home environment (silva lupus in Sabina, a wolf in my Sabine wood, 1.22.9).

The rest of the collection (Odes 1.23-38) depicts specific examples of the poet's general view on space and time as portrayed in the poems in the preceding section of the collection (Odes 1.1-22). As can be expected, poems in the section depicting specific examples (Odes 1.23-38) are organized in small clusters representing individual aspects of a theme identified and presented previously (Odes 1.1-22). In this latter section (Odes 1.1-22) space was associated with mental space and insight rather than geographic position. Time was portrayed as being largely under the control of the individual. Wasting time was to be avoided.

It is significant that where the first section of the collection (Odes 1.1-22) started with space and the individual's situation in a more or less fixed place in space caused by birth and talent (for which a person was not personally responsible), the second section of the collection (Odes 1.23-38) focuses on time - something for which the individual is indeed personally responsible. It is therefore appropriate that when the poet turns to personal responsibility for using time properly, he starts this section of the collection with three distinct examples.

7. Odes book 1.23-1.25: Three different responses to the challenge posed by limited time

\subsection{Odes 1.23: Carpe diem ignored}

Odes 1.22 concluded the previous cluster of poems by indicating that the lyric poet was protected from threats in the present, because he had dedicated all his time to writing poetry in praise of a powerful goddess. The next three poems (Odes 1.23-25) give examples of other ways in which to spend one's time. In Odes 1.23 (vitas hinnuleo me similis, Chlö̈ / quaerenti pavidam ... / matrem non

51 pone sub curru nimium propinqui / solis in terra domibus negata: / dulce ridentem Lalagen amabo, / dulce loquentem (Odes 1.22.21-24), place me under the chariot of the sun, too close to the earth, empty of structures, I will love my sweetly laughing, sweettalking Lalage. 
sine vano ... metu, you avoid me, Chloë, like a young deer, with senseless fear of drafts and copses ... [a young deer] searching for its nervous mother, 1.23.1-4) Chloë refuses to grasp the fleeing moment, because of her youth and her inexperience. She has not grasped the implications of time passing. Like the deer, she is focused on senseless fears, but unlike the deer (ignorant of any sense of time) she indeed overlooks the real threat — that of time passing.

\subsection{Odes 1.24: Carpe diem achieved}

Odes 1.24 (quis desiderio sit pudor aut modus / tam cari capitis? what curb or check should there be to mourning someone so valued? ... 1.24.1-2) is a reprimand to Vergil. When confronted with an outstanding example of someone who spent his time well, Vergil reacts by wasting his own time in mourning something that cannot be changed. ${ }^{52}$ He refuses to find solace in the fact that Quintilian should indeed be praised for making the most of the time he had. Quintilian should therefore not be mourned but rather taken as example.

\subsection{Odes 1.25: Regret for not grasping the moment (carpe diem ignored)}

Odes 1.25 (parcius iunctas quatiunt fenestras, less frequently do randy young men shake your closed windows ) depicts a classic example of the regret associated with the realization that time has run out and that there is no hope for the future. If the future is as frightening as is threatened in the poem, capitalizing on the present makes good sense. Horace paints an all-too-graphic picture of the awful future awaiting Lydia if she ignores the opportunities of the present. This is a last ditch attempt to persuade her to seize the moment and not let the present just slip by.

Time remains the central theme in the next three odes. In this case the poet, always the realist, focuses not on the constructive use of time (or not), but on the coping mechanisms employed to overcome difficult situations. It is not only a matter of making the most of the time we have. Very often it is a question of coping with some of the difficulties associated with the moment. In this section the poems do not reflect the encouragement: carpe diem. It is a matter of supera diem (survive the day).

52 See Akbar Kahn's illuminating article on the poem (1999:73-84). 


\section{8. $\quad$ Odes book 1.26-1.28: Coping with difficult situations}

8.1 Odes 1.26: Cope by means of creative effort, aided by the muse

Future regret as threat underpins the common theme of the next three poems. They focus on aid for the poet to overcome one of the most pervasive challenges faced by man: not only grasping the moment, but all too often also having to cope with it. In fact in the first line of Odes 1.26 (musis amicus tristitiam et metus / tradam protervis ... ventis, as one beloved to the muses, I shall drive out sorrow and dread towards the rough winds, $1.261-2$ ) the poet proclaims that protected by the muses, he is able to banish all negative feelings from his mind, also those associated with the inability to make the most of the moment by continuing his creative efforts (nil sine te mei / prosunt honores, without you [o muse] my efforts are of no use, 1.26.9-10). In so doing the poem picks up on the remorse and fear presented in the previous poem (Odes 1.25 9-20) where the inexorable passage of time underlined the necessity of making the most of the current moment. In the present poem (1.26) the muse comes to the poet's aid supporting his creative efforts which, in the form of a poem, can escape the destruction associated with the passage of time.

\subsection{Odes 1.27: Cope by means of creative effort aided by Bacchus}

Odes 1.27 (natis in usum laetitiae scyphis / pugnare thracum est, it is a Thracian custom to fight amid glasses used for pleasure ) dwells on how Bacchus aids the poet, by means of wine used in moderation, to create a poem. The poet will drink the proferred Falernian (vultis severi me quoque sumere partem Felerni? You want me to drink some of the robust Falernian? 1.27.9-10), if the victim of an overwhelming passion agrees to talk about his situation (non alia bibam/ mercede, with no other payment will I drink, 1.27.13-14). By describing the situation in a poem, the great vortex of emotions overwhelming the victim, is made clear (quanta laboras in Charybdi, in what great spiraling current do you toil, 1.27.19). The sufferer (a miser ... puer, ah, miserable youth, 1.27.18-20) has to cope with his painful condition, from which previously not even mythical Pegasus could have saved him (vix ... te ... Pegasus expediet, 1.27.23-24). Using this example, the poet suggests that an overwhelming situation can be brought under some control if the victim can bring himself to describe his feelings in words. Since the poet states that his own participation in the feast depends on the sufferer talking, peer pressure is brought to bear. Supposedly the sufferer should talk lest the poet leave. The real aim of the request is, of course, not this quid pro quo. The aim is to get the miser puer to share his experience and maybe to find some relief by unburdening 
his soul to sympathetic ears (quidquid habes, age,/ depone tutis auribus, Odes 1.27.17-18).

The implication is that the creative effort required to put an emotional experience into words, gives the experience structure ( $c f$. Catullus 8 ). In the present scenario a little support from Bacchus may help overcome the initial difficulties, as well as the fact that the poet has already anticipated the sufferer's words by describing his condition in great detail (1.27.14-24). Not much remains to be told. The difficulties of the present can indeed be mastered by creative effort.

\subsection{Odes 1.28: Cope because of the constraints of necessity}

Odes 1.28 (te maris et terrae numeroque carentis harenae / mensorem, you, who delineate the sea and the land and sand without number, 1.28.1-2) puts the previous two poems into a harsh context by addressing the words of the poem to a corpse. Odes 1.26 and 1.27 both focused on ways in which to cope with difficult circumstances. Odes 1.28 comes to the conclusion that endless agonizing over a situation is an indulgence. In reality time is finite: one darkness awaits all humankind and the road ending in death must be followed only once (sed omnes una manet nox / et calcanda semel via leti, but one night waits for all, and the path of death must be paced only once, 1.28.15). An individual has to cope with whatever confronts him because death terminates all options. The luxury of not coping is in fact a denial of death. This attitude of not coping represents a lack of insight into the human condition where time is finite.

\section{Odes book 1.29-1.32: Hostile circumstances regarding time - examples}

The next four poems (Odes 1.29-1.32) form another cluster. This cluster illustrates the conclusion reached in the previous three odes (1.26-1.28) by giving specific examples of how this lack of insight into the fact that limited time is basic to the human condition, is manifested. The focus is on individuals who demonstrate this deficiency and lack of understanding by squandering time on misguided objectives.

\subsection{Odes 1.29: The quest for fame}

Odes 1.29 (Icci, beatis nunc Arabum invides gazis, Iccius now you are envious of the rich treasures of the Arabians) depicts Iccius who had promise as a scholar (pollicitus meliora, you promised better things, 1.29.16), but who now turns his attention to an ill-suited quest for fame and fortune as a soldier. He makes such inappropriate use of his time, that it equals an attempt at changing the laws of physics and bringing about a condition where water flows backwards (1.29.10-11). If Iccius's actions represent the denial of a generally accepted law of physics, his 
actions equally represent his misunderstanding of another law of nature. In the human condition, time is finite. It is a crime to miss-apply that time by inappropriate pursuits.

\subsection{Odes 1.30: Quest for eternal youth}

Odes 1.30 (O Venus, regina Cnidi Pahique, o Venus, queen of Cnidos and Paphos ) describes an invocation to Venus and other mythical beings (Cupid, the Graces, the Nymphs and Mercury) to come to Glycera's aid, obviously in a plea for success in love. The irony of the poem lies in an appeal that Youth (iuventas) also should accompany the group. Not only is this a misguided request for time not to pass, but also an unrealistic appeal for youth always to be allied with love (parum comis sine te Iuventas, and without you (O Venus) youth is insufficiently pleasing, 1.30.7). The desire not only for unlimited time (eternal youth), but also to have this condition accompanied by love implies a rather harsh rejection of the imperfect present even though this present is the prerequisite for the human condition.

\subsection{Odes 1.31: What constitutes a likely request with regard to time?}

After two such examples of misdirected effort, Odes 1.31 (quid dedicatum poscit Apollinem / vates? what does the poet require from consecrated Apollo?) turns to what the poet would consider to be a sensible request from the gods. Except for its final request, the entire poem lists what the poet does not need. This underlines the importance of what the poet does ask from Apollo in the end: contentment, a sound body in a sound mind, and continued poetic creativity (frui paratis et valido mihi, / Latoe, dones et, precor, integra / cum mente, nec turpem senectam/ degere nec cithara carentem, let me enjoy what I have, o son of Latona, healthy in body with a sound mind and I pray, not to spend a difficult old age and not lacking [power over] the lyre, 1.31.17-20). No philosopher could come up with a more appropriate request to direct to the gods. No human being could ask for more.

\subsection{Odes 1.32 : What constitutes a likely quid pro quo with regard to time?}

Immediately following this realistic request, the poet acknowledges its comprehensiveness. In Odes 1.32 (poscimur. si quid uacui sub umbra, lusimus tecum, I am asked. If idle, I've ever played with you in the shade [o lyre],1.32.1-2) he therefore recognises the debt he owes to the gods with one single word poscimur: I am asked. This implies that as the gods are asked to perform so, too, 
the poet must respond to requests made of him. ${ }^{53}$ This poem ends the cluster that started with two examples of time misspent: Iccius engaging in a quest as futile as an attempt to ignore the laws of physics (to make water flow backwards, Odes 1.29) and a request for eternal youth aligned with love (Odes 1.30). ${ }^{54}$ The cluster now ends with the poet taking up his responsibilities. If he requested contentment, a sound mind, a sound body and continued mastery over his lyre (nec cithara carentem, Odes 1.31.20), he now acknowledges the quid pro quo caused by his request and the poet asks his lyre for help (salve / rite vocanti, duly be auspicious to him who calls on you, 1.32.15-16) so that he too may fulfil his obligations and produce a poem.

\section{Odes book 1.33-1.35: Hostile circumstances regarding space}

Early in the collection (Odes 1.1-1.9) the poet's description of space and time underlined the individual's limited control over both. The cluster in Odes1.29-1.32 presented individuals not understanding the impact of time on their lives. The poems focused on two unlikely quests: Iccius looking for fame as a soldier instead of as a scholar, and an appeal to Venus to grant eternal youth aligned with love. In this next cluster (1.33-1.35) the individual is at the mercy of the space in which he finds himself. This larger environment is capricious. Although the poet has some control over his lyre, ironically this only serves to underline his overall vulnerability.

\subsection{Odes 1.33: Hostile circumstances attributed to Venus}

In Odes 1.33 (Albi, ne doleas plus nimio memor / immitis Glycerae, do not, O Albius, mourn more than is fitting, in memory of harsh Glycera ) a malicious Venus delights in her power over individuals (sic visum Veneri, cui placet impares / formas atque animos sub iuga aënea / saevo mittere cum ioco, this is Venus's vision, whose pleasure it is in savage enjoyment to bind together under her bronze yoke, bodies and minds that do not fit, 1.33.10-12). In the poem there is no solution to this situation. The individual is the minion and as such subjected to the wilfulness of a capricious divine ruler, Venus. There is only one way to cope: an ironic acknowledgement of the reality of the situation $(1.33 .13-16){ }^{55}$

53 A quid pro quo can be expected in a society where reciprocity supports all social intercourse.

54 The mythological examples of how this turns out should be sufficient deterrent.

55 ipsum me melior cum peteret Venus, / grata detinuit compede Myrtale / libertina, fretis acrior Hadriae / curvantis Calabros sinus, when a better Venus sought me out, freed Myrtale retained me in pleasant confinement, Myrtale more destructive than the breakers of the Adriatic curving round the gulf of Calabria,1.33.13-16. 


\subsection{Odes 1.34: hostile circumstances attributed to Fortune}

In Odes 1.34 (parcus deorum cultor et infrequens, a cautious and sporadic celebrant of the gods) Jupiter is all-powerful (valet ... deus, 1.34.12-13) and delights in being unpredictable. His power manifests itself in Fortuna's wilful pleasure in generating change in the situation of the individual (hinc apicem rapax / Fortuna ... sustulit, hic posuisse gaudet, from him Fortune seizes the crown, relishing to dispose of it elsewhere, 1.34.14-16). If the individual has not yet realised that circumstances are not under his control, the poet sums it up for him: valet ima summis mutare (1.32.12-13). The extremes involved are striking: the lowest has the power to change with the highest. This represents not just a slight adjustment. This is fundamental change which confronts human beings on an ongoing basis. A thinking human being should at least acknowledge this reality, especially one who starts out as knowledgeable in a kind of wisdom that the rest of the poem proves is not wisdom at all (insanientis dum sapientiae / consultus erro, 1.34.2-3).

\subsection{Odes 1.35: Hostile circumstances in general}

Odes 1.35 (O diva, gratum quae regis Antium, $\mathrm{O}$ goddess, who rules over Antium) brings the cluster on the unfavourable environment to an end with a detailed description of a hostile environment, savouring its powers over the individual. Fate and necessity determine both the space (de gradu, from [a lowly] position, 1.35.2) and the time (mortale corpus, the finite body 1.35.3) allotted to any individual. To a significant degree Fate and necessity also control the political organisation or state (imperiumque frangat, [bringing] the ruling power to ruin, 1.35.16). If the state is ruined, the environment of the individual changes fundamentally. This condition forces the individuals concerned to acknowledge their vulnerability and admit to their powerlessness vis-à-vis the state and therefore also to the world at large. It brings the individual to the required insight into his vulnerable position in the world - a final assessment without which the individual will not be able to make sense of his circumstances. Subsequently, it forces the individual to focus on what is possible in the future regarding both time and space, in spite of a hostile environment.

\section{Odes book 1.36-1.38: Final views on space and time}

\subsection{Odes 1.36: Philosophical overview of individual space and time}

The last cluster in the collection begins with Odes 1.36 (et ture et fidibus iuvat / placare, and with incense and strings may it help to please, 1.36.1-2), a 
prosphonetikon, welcoming the voyager back from his travels. It is striking to note that Odes 1.36, the third-last poem in the collection, is a direct parallel to Odes 1.3. This latter poem, a propemptikon, begged for Vergil's safe return from his voyage. The outcome of Vergil's journey at the beginning of the collection was open. The happy return in Odes 1.36 suggests that some stocktaking of the poetic journey undertaken through the collection would not be misplaced.

\subsection{Odes 1.37: Example of an exceptional individual's use of space and time}

Celebration would certainly be associated with the first line of the next poem, Odes 1.37 (nunc est bibendum, nunc pede libero / pulsanda tellus, now is the time to drink, now the time for the ground to be stomped with feet that are free, 1.37.1-2). However, the joyful celebration called for because of the defeat of Anthony and Cleopatra is not as straightforward as might be expected. The downfall of Cleopatra represents the conquest of an arch-enemy of Rome. It also portrays an admirable woman, who with remarkable self-discipline takes control of her own circumstances (her own space) and of the time allotted to her. In spite of a hostile environment, she indeed manages to achieve all that an individual can hope to achieve mentally. It is striking that Horace presents Cleopatra, a foreigner, an enemy of the state and a woman, as the example of an individual taking control of her own space and time. In so doing she copes with an indifferent environment represented metaphorically by the wilful maliciousness of the gods (as portrayed inter alia by Odes 1.33-1.35) with exemplary fortitude.

\subsection{Odes 1.38: Example of an ordinary individual's use of space and time}

Exactly because the world is indifferent, another alternative is presented by the final poem in book 1 of the collection, Odes 1.38 (persicos odi, puer, apparatus, I hate Persian splendour, my good fellow, 1.38.1). This is the simplest poem in the whole collection. As opposed to an example from history, Cleopatra, who coped courageously with a spectacular individual fate, Horace illustrates how he, as an ordinary individual, manages his own time and space. He focuses on essentials. He does not look for what is past (rosa ... sera, the late rose, 1.38.3-4). He is satisfied with his space and does not embellish his environment in vain (simplici myrto nihil adlabores, add nothing to the modest myrtle, 1.38.5) ${ }^{56}$ In short, in spite of the preceding rather harsh portrayal of the human condition, Horace, in this last poem of book 1, radiates the very contentment that he had begged from the gods in Odes 1.31 .

56 Cf. Syndikus 1973:19 who points out 'dass für den Menschen im scheinbar Alltäglichsten und ohne Mühe Erreichbaren das Glück und das Heil liegen kann'. 


\section{Conclusion}

This illustration of contentment is the concluding statement on Horace's ideas on time and space depicted in this first book of the Odes. In an unpredictable environment, individuals determine very little. They have little influence on where they are. They have even less influence on how much time they have. Individuals only have control over how they manage their specific space and time. If an individual understands his relative position in the cosmic order, he is in a better position to make the most of this situation, even if the latter is not to his liking.

In his Odes book 1 the poet Horace in his own unique way explained how he saw the world and in doing so he attempted to make sense of the human condition. The carefully constructed sequence of poems reflected in book 1 of the Odes seems to suggest that Horace also came to grips with some of the main ideas and aims of both the Epicureans and the Stoics. The philosophical ideas imbedded in the poems may not be new, but how Horace hinted at these ideas by means of the very sequence in which specific poems appear, is uniquely Horatian.

The philosophy reflected in the sequence of the poems may contain only a fleeting reference to Horace's interpretation of such philosophies, but the lyric poet has drawn his line in the sand and has staked his claim to fame. His poems do not only match up to those of his Greek predecessors with regards to metre. His poems, by the very order in which they appear, also hint at a larger philosophical frame of reference. If the interpretation of this philosophical environment is idiosyncratic, this is the prerogative of the lyric poet's iocosa lyra. In the final analysis, this lyric poet can claim contentment with his situation as reflected in Odes $1.38^{57}$ - and any philosopher would do well to do better.

\section{BIBLIOGRAPHY}

Anderson, W S (ed). 1999. Why Horace? A collection of interpretations. Wauconda: Bolchazy-Carducci Publishers.

Collinge, N E 1961. The structure of Horace's Odes. London: Oxford University Press.

Commager, S 1962. The odes of Horace: A critical study. New Haven: Yale University Press.

Davis, G 1991. Polyhymnia: The rhetoric of Horatian lyric discourse. Berkeley: University of California Press.

Frankel, E 1957. Horace. Oxford: Clarendon.

57 Indeed, Horace's situation embodies both the Epicurean and Stoic ideals of selfsufficiency (autarkeia) and contentment, freedom from anxiety (ataraxia) as well as the Stoic idea of happiness (eudaimonia). 
Kahn, H Akbar. 1999. Horace's ode to Virgil on the death of Quintilius: 1.24. In Anderson, W S, Why Horace? A collection of interpretations, 73-84.

Kiessling, A and Heinze, R, with addenda by Burck, E 1958. Q. Horatius Flaccus Oden und Epoden $\left(9^{\text {th }}\right.$ edition $)$. Berlin. Weidmannsche Verlagsbuchhandlung.

McClatchy, J D (ed). 2002. Horace the Odes: New translations by contemporary poets. Princeton, N J: Princeton University Press.

Nisbet, R G M \& Hubbard, M 1970. A commentary on Horace Odes, Book 1. Oxford: Clarendon Press.

Pomeroy, A J 1999. A man at a spring: Horace Odes 1.1. In Anderson, W S, Why Horace? A collection of interpretations, 3-19.

Santirocco, M 1986. Unity and design in Horace's Odes. Chapel Hill: University of North Carolina Press.

Schenker, D J 1993. Poetic voices in the Roman Odes. CJ 88.2:147-166.

Syndikus, H P 1989. Die Lyrik des Horaz I. Darmstadt: Wissenschaftliche Buchgesellschaft.

Van Sickle, J 2004. The design of Virgil's Bucolics ( $2^{\text {nd }}$ edition). London: Bristol Classical Press.

Von Albrecht, M 1995. Horaz und die europäische Literatur. Gymnasium 102.4:289-304.

West, D 1995. Horace Odes 1: Carpe diem. Text, translation and commentary. Oxford: Clarendon Press.

Zetzel, Z E G 1980. Horace's Liber Sermonum: The structure of ambiguity. Arethusa 13:59-77. 